\title{
Farklı Tane Mısır (Zea mays L.) Çeşitlerinin Besleme Değerlerinin Belirlenmesi
}

\author{
Bilal KESKİN* Hakkı AKDENİZ Süleyman TEMEL Barıș EREN \\ Iğdır Üniversitesi, Ziraat Fakültesi, Tarla Bitkileri Bölümü, 7600, IĞDIR \\ (*Sorumlu yazar e-mail:bilalkeskin66@yahoo.com)
}

\section{Geliş Tarihi :01.11.2017}

\author{
Kabul Tarihi :30.11.2017
}

\begin{abstract}
ÖZET : Bu araștırma Iğdır Üniversitesi Ziraat Fakültesi deneme alanlarında 10 adet RX-9292, SHEMALL, OSSK-602, 71 MAY 69, OSSK-596, OSSK-644, TK-6063, 72-MAY-80, HiDO ve TK-6060 mısır çeşidi kullanılarak tesadüf blokları deneme desenine göre üç tekrarlamalı olarak kurulmuştur. Araştırmada kullanılan mısır çeşitlerinin tanelerinde ham protein (HP), nötr deterjan lif (NDF), asit deterjan lif (ADF), asit deterjan lignin (ADL), kuru madde sindirilebilirliği (KMS), sindirilebilir enerji (SE), metabolik enerji (ME), kuru madde tüketimi (KMT), nispi yem değeri (NYD) belirlenmiştir. Araştırma sonuçlara göre en yüksek ham protein oranları RX-9292, SHEMALL, OSSK-602 ve 71 MAY 69 cesitlerinden elde edilmistir. En düsük NDF ve ADF oranları sırasıyla \%26.8 ve \%2.72 olarak 71 MAY 69 çeşidinden elde edilmiştir. Bunun birlikte en yüksek kuru madde sindirilebilirliği \% 86.8, sindirilebilir enerji değeri $3.98 \mathrm{Mcal} \mathrm{kg}^{-1}$, metabolik enerji değeri $3.27 \mathrm{Mcal} \mathrm{kg}^{-1}$ ve en yüksek KMT (Kuru madde tüketim oranı), \%4.54 ve nispi yem değeri en yüksek 305.5 olan 71 MAY 69 çeşidi hayvan besleme için önerilebilir.
\end{abstract}

Anahtar Kelimler: Tane mısır, çeşit, besin değerleri

\section{Determination of Feeding Values of Different Grain Corn (Zea mays L.) Varieties}

\begin{abstract}
In this research, 10 RX-9292, SHEMALL, OSSK-602, 71 MAY 69, OSSK-596, OSSK-644, TK-6063, 72-MAY80, HIDO and TK-6060 maize types were used in the experiment areas of the Agricultural Faculty of Iğdır University. In this study, CP (Crude protein), NDF (Neutral Detergent Fiber), ADF (Acid Detergent Fiber) ADL (Acid Detergent Lignin), DMD (Dry matter digestibility), DE (Digestible energy), ME (Metabolizable energy), DMI (Dry matter intake), RFV (Relative feed value) contents of grain of corn varieties was determined. The random blocks were set up with three replications according to the trial design. According to the results obtained, the highest crude protein ratios were obtained from RX-9292, SHEMALL, OSSK602, and 71 MAY 69 varieties. The lowest NDF (Neutral Detergent Fiber) and ADF (Acid Detergent Fiber) ratios were 26.8\% and $2.72 \%$, respectively, of 71 MAY 69. The highest DMD (Dry matter digestibility) was $86.8 \%$, the digestible energy value was $3.98 \mathrm{Mcal} \mathrm{kg}^{-1}$, the metabolic energy value was $3.27 \mathrm{Mcal} \mathrm{kg}^{-1}$, the highest DMI (Dry matter intake) was $4.54 \%$ and the RFV (Relative feed value) was highest at 305.5 71 MAY 69 genotype may be suggested for animal feeding.
\end{abstract}

Keywords: Grain corn, varieties, nutritional value

\section{GİRIş}

Son yıllarda Türkiye de artan hayvan sayısına bağlı olarak yem bitkisi üretim miktarlarındaki artışın yetersiz kalması ve özellikle kış döneminde hayvanların yetersiz beslenmesi, silajlik yem bitkilerinin üretimini arttırmıştır. Bu anlamda mısır (Zea mays L.) ülkemizde ve dünyada hayvanların yem ihtiyacını karşılayan ve genellikle silaj olarak kullanılan bir yem bitkisidir (Başbağ vd., 1997). Mısır özellikle son yarım yüzyılda yüksek besleme değeri ve lezzetlilik özelliklerinden dolayı silajlık yem üretimi noktasında dünya genelinde üretimi artan bir bitki olarak kabul görmüştür. Bununla birlikte birim alandaki yeşil ot veriminin yüksek olması ve katkı maddesi gerekmeksizin silaj yapımına uygun olması en önemli özelliklerindendir. Mısır bitkisi saydığımız bu özelliklerinden dolayı hayvanların gereksinim duyduğu yem açığının giderilmesi açısından üretimine verilen önem artmaktadır. (Açıkgöz, 2001; Kılıç, 1986; Sade, 2002). Ülkemizde silaj yapımında kullanılan çok çeşitli bitkiler bulunmaktadır. Bu bitkiler içerisinde en fazla mısır ve sorgum türlerinin üretimi yapıldı̆̆ 1 söylenebilir (Sağlamtimur vd., 1998).

Bir sicak iklim bitkisi olan misır (Zea mays L.) modern dünyada çok yönlü kullanımıyla en önemli dane ürünü haline gelmiş, insan beslenmesinde buğday ve çeltikten sonra en fazla kullanılan bitkilerin başında gelmekte olup gelişmiş ülkelerde büyük oranda hayvan yemi olarak tüketilmektedir (Kırtok, 1998). Yüksek protein ve özellikle A vitamini yönünden zengin olan danenin $\% 82.5$ kısmını endosperm oluşturarak iyi bir konsantre yem olarak kullanılmaktadir. Hayvan beslemede kullanilan kaba yemler yapisal olan ve olmayan karbonhidratlardan oluşur (Tekce ve Gül 2014). Tek mideli hayvanlar kaba yemlerdeki bu yapisal karbonhidratları sindiremezken, ruminantlar selülotik mikroorganizmalar sayesinde yapisal karbonhidratları sindirebilmektedirler. Kaba yemlerde bulunan yapisal karbonhidratlar NDF (selüloz, hemiselüloz ve lignin), ADF (selüloz, hemiselüloz) olarak iki gruba ayrilır. Yapısal karbonhidratların hayvan beslemede kullanımı, ruminantlarda yemlerde yararlanmanın artırılması ve rumen sağlı̆̆ının korunması için önemlidir.

$\mathrm{Bu}$ çalışmanın amacı, Iğdır koşullarında yetiştirilen 10 adet misır çeşidinin tanelerinin yem değerlerini belirlemek amaciyla yürütülmüştür. 


\section{MATERYAL VE METOT}

Araştırma 2015 yılında yürütülmüştür. Çalışmanın yürütüldüğü alanın iklim verileri Çizelge 1'de verilmiştir (Anonim, 2015). Araştırmanın yürütüldüğ̈̈ mart-ağustos ayları arasında ortalama sıcaklığın $23.2^{\circ} \mathrm{C}$, aylık ortalama yağışın $30.0 \mathrm{~mm}$ ve aylık ortalama nemin ise $\% 44.2$ olduğu görülmektedir.

Çizelge 1. Araştırmanın yürütüldüğü Iğdır İli’nin 2015 yılına ait bazı iklim değerleri

\begin{tabular}{|l|c|c|c|c|c|c|c|}
\hline & Mart & Nisan & Mayıs & Haziran & Temmuz & Ăgustos & Ortalama \\
\hline Ortalama Sıcaklık $\left({ }^{\circ} \mathrm{C}\right)$ & 11.0 & 16.4 & 21.3 & 28.5 & 31.8 & 30.2 & 23.2 \\
\hline Aylık Toplam Yağış (mm) & 52.0 & 44.1 & 41.5 & 27.8 & 0.3 & 14.3 & 30.0 \\
\hline Aylık Ort. Bağılı nem (\%) & 50.8 & 47.7 & 52.9 & 40.0 & 33.6 & 40.7 & 44.2 \\
\hline
\end{tabular}

Araştırma Iğdır Üniversitesi Ziraat Fakültesi deneme alanlarında 10 adet RX-9292, SHEMALL, OSSK-602, 71 MAY 69, OSSK-596, OSSK-644, TK-6063, 72-MAY-80, HIDO ve TK-6060 misir çeşidi kullanılarak tesadüf blokları deneme desenine göre üç tekrarlamalı olarak kurulmuştur.

Iğdır Üniversitesi Ziraat Fakültesi laboratuvarlarında analiz edilen deneme alanındaki topraklar kil-tın yapısında olup şiddetli alkalin $(\mathrm{pH}$ : 8.65, hafif tuzlu (EC $1.37 \mathrm{dS} \mathrm{m}^{-1}$ ), organik madde içeriği düşük $(\% 1.20)$ ve kireç bakımından (CaCO3:\%22.27) ise zengindir. Toprağın fosfor ve potasyum içeriği $0-20$ ve $20-40 \mathrm{~cm}$ derinliğe göre sirasiyla 51.7-30.15 ppm ve 852.4-576.20 ppm olarak tespit edilmiştir (Erdoğan, 2013; Kacar 2012). Tohum ekimleri 04.04.2015 tarihinde yapılmıştır. Parsel uzunluğu $5 \mathrm{~m}$, sira arası $70 \mathrm{~cm}$, sira üzeri 15 $\mathrm{cm}$ olmak üzere bir parsel alanı $17.5 \mathrm{~m}^{21}$ dir. Denemede toplam $16 \mathrm{~kg} \mathrm{da}^{-1}$ azotun yarısını ve fosforun tamamın $8 \mathrm{~kg} \mathrm{da}^{-1}$ ekimle birlikte, azotun diğer yarısını ise bitkiler $50 \mathrm{~cm}$ uzunluğa ulaştığında verilmiştir. Bitkiler 15-20 cm'ye kadar yağmurlama sulama ile ondan sonra hasada kadar karık sulama yapılmıştır. Kenar tesirler atıldıktan sonra her parselde rastgele alınan 30 bitki 07.09.2015 tarihinde hasat edilmiş ve besin değerleri analizleri yapılmıştır.

Ham protein oranı (Kacar, 1972; Akyıldı, 1984); NDF, ADF ve ADL oranları (Van Soest et al., 1991); KMS oranı $=88,9-(0,779 \times$ x \%ADF $)$ (Oddy et al., 1983); SE $=0.27+0.0428 \times(\%$ KMS $)$ (Fonnesbeck et al., 1984); ME $=0.821 \times$ SE (Mcal $\mathrm{kg}^{-1}$ ) (Khalil et al., 1986); KMT oranı $=120 /$ (\%NDF) (Sheaffer et al., 1995); NYD = (KMS x KMT) / 1,29 (Sheaffer et al., 1995)'e göre belirlenmiștir.

Elde edilen veriler SPSS paket programı ile varyans analizi ve Duncan çoklu karşılaştırma testi yapılmıştır (SPSS 1991).

\section{BULGULAR VE TARTIŞMA}

Mısır çeşitlerinin HP, NDF, ADF, ADL, KMS, SE, ME, KMT ve NYD değerleri Çizelge 2'de verilmiştir. İncelenen tüm özellikler bakımından çeşitler arasında önemli farklılıklar tespit edilmiştir.
Mısır çeşitlerinin ham protein oranları en düşük ve en yüksek olarak \%5.69 ile \%8.14 arasında değişmiş olup sırasıyla ile TK-6060 ile RX-9292 çeşitlerinden elde edilmiştir. Deneme bulguları Vartanlı ve Emekliler (2007), Ankara koşullarında hibrit mısır çeşitlerinin verim ve kalite özelliklerinin belirlenmesi üzerine yaptıkları bir çalışmadaki ham protein oranlariyla \%6.21-8.65 uyumlu, ancak Sade vd. (2002), Ayranc1 ve Sade (2004) ve Koca ve ark. (2009), Koca ve Erekul (2011) bulgularından düşük bulunmuştur. (Bressani and Conde,1961), tanenin nem içerinin \%73 den \%54'e düşmesiyle, toplam protein konsantrasyonu \%9.5 den 7.8 düştügünü ve fizyolojik olgunluğa ulaştıktan sonra fazla değişmediğini, belirtmişler. Öner (2015), misır çeşitlerinin ham protein oranlarının lokasyonlara göre değişebileceğini ve Lopes and Larkins (1991), Uribelarrea et al., (2004) ise tanenin kompozisyonu bitki türüne, endospermin genetik yapısı ile çevre şartlarına göre değişebileceğini, Julian ve ark., (2010) ise tanenin protein ve nişasta konsantrasyonları, genotip veya azot uygulamalarına bağlı olarak değiştirilebileceği belirtmişlerdir.

NDF lifli karbonhidratlardan selüloz ve hemiselüloz, lignin, sıcaklıkla zarar görmüş bir kısım proteinleri ve silisyum içeren bir yapıdır. ADF ise NDF içerisinden hemi-selüloz çıkartılmış halidir (Kutlu vd.. 2005). Araştırmada kullanılan melez mısır çeşitlerinin NDF oranları \%26.8 ile \%37.8 arasında değişmiştir. En yüksek NDF oranın OSSK596 çeşidinden ve en düşük oran ise 71 MAY 69 çeşidinden elde edilmiştir. Çeşitler ADF yönünden karşılaştırıldığında en yüksek oran $\% 4.72$ ile TK6060 çeşidinden, en düşük oran ise \%2.72 ile NDF de olduğu gibi 71 MAY 69 çeşidinden sağlanmıştır. ADL yönünden karşılaştırıldığına ise \%1.73 ile RX9292 mısır çeşidi diğerlerinden daha yüksek, \%1.13 ile de TK-6060 çeşidinden en düşük ADL miktarı elde edilmiştir. Farklı melez misır tanelerinin NDF, ADF ve ADL içeriklerinin sırasıyla \%11.02-14.72, $\% 3.63-4.76$ ve \%0.36-0.80 arasında değiştiğini belirlemişlerdir (Zilic et al., 2011). NDF oranının kuru madde esasına göre \%25-32 arasında hayvanlardan optimum düzeyde verim 
alınabilmektedir. Yemlerinde NDF azlığ 1 ise rumen fermentasyonunda değişikliğe sebep olarak enerji eksikliğinden kaynaklanan metabolik hastalıklar oluşmaktadır (Calsamiglia et al., 2008). Bundan dolayı hayvanların günlük tükettikleri otun NDF içeriğinin \%45.8, ADF içeriğininin \%25 ve ADL içeriğinin de \%10'dan fazla olması istenmemektedir (NRC, 2001). Parissi et al., (2005), hücre duvarının gelişmesinin, bitkinin gelişmesi ile alakalı olduğunu ve bitkiler olgunlaştıkça NDF ve ADF gibi hücre duvarı bileşiklerinin arttı̆ını, HP gibi protoplazma bileşiklerinin ise azaldığını belirtmişlerdir.

Misır çeşitlerinin tanelerinin kuru madde sindirilebilirliği oranı en yüksek olarak $\% 86.8$ ile 71 MAY 69 çeşidinden, en düşük oran ise \%85.2 ile TK-6060 çeşidinden elde edilmiş ve diğer çeşitlerin KMS oranları bu iki değer arasında değişmiştir. Yiğit ve Ustaoğlu (2003), hayvan rasyonları hazırlanırken yem materyali ve sindirilme oranının bilinmesi maliyet açısından önem teşkil etmektedir. Farklı mısır çeşitlerinin besin madde ve teknolojik özelliklerini araştıran Zilic et al., (2011), nişasta oran1 $\% 55.32$ ve $\% 54.59$, lignin oran $\% 0.39$ ve
\%0.45 olan şeker misır çeşitlerinin kuru madde sindirilebilirlikleri surasıyla \%92.69 ve \%91.07 olarak belirlemiş, yani nişastanın azalması ve ligninin artmasıyla KMS azalmıştır. İn-vitro yöntemlerden enzim tekniği ile arpa ve mısırın organik madde sindirilme oranını $\% 88.50$ ve $\% 92.20$ olarak, Yazıcıŏlu ve Yeldan (1987) aynı materyalin sindirilme oranını sirasiyla $\% 71.57$ ve $\% 70.32$ bulmuşlardır. Denek ve Deniz (2003) yaptıkları araştırmada mısır, arpa, buğday, çavdar, yulaf ve tritikale tane yemlerin kuru madde sindirilme derecelerini $(\% 83.81,79,86,81.34,83.05,75.50$ ve 84.0) olarak bizim bulgularımızla paralellik arz etmektedir. Akdeniz vd., (2003), sicak iklim bitkisi olan bazı tane sorgum çeşitlerinin sindirilebilirlik oranlarını \% 73.85 ile \% 95.56 arasındaki olduğunu ve misır ile mukayese edildiğinde sorgumdaki değişim daha fazla olduğu görülmektedir. Taneleri kimyasal kompozisyonu ve besleme değerinin genotip, iklim, toprak yapısı ve gübreleme gibi faktörler tarafından etkilendiği belirtilmiştir (Ebadi vd., 2005).

Çizelge 2. Farklı Mısır (Zea mays L.) Çeşitlerinin Besleme Değerleri

\begin{tabular}{|c|c|c|c|c|c|c|c|c|c|}
\hline $\begin{array}{l}\text { Mısır } \\
\text { Çeşitleri }\end{array}$ & \begin{tabular}{|l} 
Ham \\
Protein \\
Oranı \\
$(\%)$
\end{tabular} & $\begin{array}{l}\text { NDF } \\
\text { Oranı } \\
(\%)\end{array}$ & $\begin{array}{l}\text { ADF } \\
\text { Oranı } \\
(\%)\end{array}$ & $\begin{array}{l}\text { ADL } \\
\text { Oranı } \\
(\%)\end{array}$ & $\begin{array}{l}\text { KMS } \\
\text { Oranı } \\
(\%)\end{array}$ & $\mid \begin{array}{l}\mathrm{SE} \\
\left(\mathrm{Mcal} \mathbf{k g}^{-1}\right)\end{array}$ & $\begin{array}{l}\text { ME } \\
(\text { Mcal kg-1) }\end{array}$ & $\begin{array}{l}\text { KMT } \\
\text { Oranı } \\
(\%)\end{array}$ & \begin{tabular}{|l} 
Nisbi Yem \\
Değeri \\
NYD
\end{tabular} \\
\hline RX-9292 & $8.14 \mathrm{a}$ & $32.4 \mathrm{abc}$ & $3.58 \mathrm{bc}$ & $1.73 \mathrm{a}$ & $86.1 \mathrm{ab}$ & $3.95 \mathrm{~b}$ & $3.27 \mathrm{a}$ & $3.73 \mathrm{abc}$ & $248.9 \mathrm{bc}$ \\
\hline SHEMALL & $7.83 \mathrm{a}$ & $29.3 \mathrm{bc}$ & $3.47 \mathrm{bc}$ & $1.26 \mathrm{ab}$ & $86.2 \mathrm{ab}$ & $3.96 \mathrm{ab}$ & $3.25 \mathrm{ab}$ & $4.14 \mathrm{ab}$ & $276.5 \mathrm{ab}$ \\
\hline OSSK-602 & $7.70 \mathrm{a}$ & $28.5 \mathrm{bc}$ & $3.80 \mathrm{~b}$ & $1.30 \mathrm{ab}$ & $85.9 \mathrm{~b}$ & $3.95 \mathrm{~b}$ & $3.24 \mathrm{~b}$ & $4.24 \mathrm{ab}$ & $285.3 \mathrm{ab}$ \\
\hline 71 MAY 69 & $7.61 \mathrm{a}$ & $26.8 \mathrm{c}$ & $2.72 \mathrm{c}$ & $1.65 \mathrm{ab}$ & $86.8 \mathrm{a}$ & $3.98 \mathrm{a}$ & $3.27 \mathrm{a}$ & $4.54 \mathrm{a}$ & $305.5 \mathrm{a}$ \\
\hline OSSK-596 & $7.41 \mathrm{a}$ & $37.8 \mathrm{a}$ & $4.17 \mathrm{ab}$ & $1.18 \mathrm{ab}$ & $85.6 \mathrm{bc}$ & $3.94 \mathrm{bc}$ & $3.23 \mathrm{bc}$ & $3.19 \mathrm{c}$ & $211.9 \mathrm{c}$ \\
\hline OSSK-644 & $7.00 \mathrm{ab}$ & $32.2 \mathrm{ab}$ & $3.48 \mathrm{bc}$ & $1.54 \mathrm{ab}$ & $86.2 \mathrm{ab}$ & $3.96 \mathrm{ab}$ & $3.25 \mathrm{ab}$ & $3.63 \mathrm{bc}$ & $242.2 \mathrm{bc}$ \\
\hline TK-6063 & $6.93 \mathrm{ab}$ & $28.1 \mathrm{bc}$ & $3.74 \mathrm{~b}$ & $1.13 \mathrm{~b}$ & $85.9 \mathrm{~b}$ & $3.95 \mathrm{~b}$ & $3.24 \mathrm{~b}$ & $4.31 \mathrm{ab}$ & $287.5 \mathrm{ab}$ \\
\hline 72-MAY-80 & $06.57 \mathrm{ab}$ & $34.4 \mathrm{ab}$ & $3.40 \mathrm{bc}$ & $1.50 \mathrm{ab}$ & $86.3 \mathrm{ab}$ & $3.96 \mathrm{ab}$ & $3.25 \mathrm{ab}$ & $3.51 \mathrm{bc}$ & $234.4 \mathrm{bc}$ \\
\hline HİDO & $6.53 \mathrm{ab}$ & $33.0 \mathrm{abc}$ & $3.84 \mathrm{~b}$ & $1.52 \mathrm{ab}$ & $85.9 \mathrm{~b}$ & $3.95 \mathrm{~b}$ & $3.23 \mathrm{bc}$ & $3.67 \mathrm{bc}$ & $244.5 \mathrm{bc}$ \\
\hline TK-6060 & $5.69 \mathrm{~b}$ & 30.4 bc & $4.72 \mathrm{a}$ & $1.13 \mathrm{~b}$ & $85.2 \mathrm{c}$ & $3.92 \mathrm{c}$ & $3.22 \mathrm{c}$ & $3.97 \mathrm{abc}$ & $262.3 \mathrm{abc}$ \\
\hline
\end{tabular}

*Aynı sütundaki farklı harf taşıyan değerler istatistiksel olarak birbirinden farklıdır.

Misır tanelerinin sindirilebilir enerji değerleri 3.92 ile $3.98 \mathrm{Mcal} \mathrm{kg}^{-1}$ olarak birbirine çok yakın değişim göstermiş ve önemli bulunmuştur. Çeşitler arasında TK-6060 en düşük enerji değerine sahip olmuştur. Metabolik enerji yönünden ortalamalar birbirine çok yakın gruplandırma göstermiş olup, 3.22 ile $3.27 \mathrm{Mcal} \mathrm{\textrm {kg } ^ { - 1 }}$ arasında değişmiş ve sindirilebilir enerjide olduğu gibi en düşük metabolik enerji TK-6060 çeşidinden sağlanmıştır. Hayvan yemlerinde selüloz ve ligninden oluşan $\mathrm{ADF}$ ise geviş getiren hayvanlar için enerji göstergesi olarak kullanılmaktadır (Anonim 2011). Denek ve Deniz (2003) mısır, arpa, buğday, çavdar, yulaf ve tritikale tane yemlerin sindirilebilir enerji değerlerini $(\% 15.94,15.49,15.64,15.93,14.62$ ve $16.12 \mathrm{Mcal}$ $\left.\mathrm{kg}^{-1}\right)$ ve metabolik enerji değerleri (\%13.52, 12.76, $12.98,13.12,12.39$ ve 13.23 Mcal $\mathrm{kg}^{-1}$ bizim bulgularımızdan oldukça yüksek bulunmuştur.

Mısır çeşitlerinin kuru madde tüketim oranı en düşük \%3.19 ile en yüksek \%4.54 arasına değişmiş olup sirasıyla OSSK-596 ile 71 MAY 69 çeşidinden elde edilmiştir. Nispi yem değerleri ise en düşük 211.9 , en yüksek 305.5 oran ile sirasiyla OSSK-596 ve 71 MAY 69 çeşitlerinden elde edilmiştir.

\section{SONUC VE ÖNERILER}

Araştırmada kullanılan 10 mısır çeşidinin tanelerindeki HP oranı \%5.69-8.14, NDF oran \%26.8-37.8, ADF oran1 \% 2.72-4.72, ADL oran1 $\% 1.13-1.73$, \% KMS oran1 \%85.2-86.8, SE 3.92-3.98 
Mcal kg-1, ME 3.22-3.27 Mcal kg-1, KMT oranı \%3.19-4.54 ve NYD değeri 211.9-305.5 arasında değişmiştir. KMS, SE, ME, KMT ve NYD değerlerinin yüksek olması, NDF ve ADF oranlarının düşük olması nedeniyle 71 MAY 69 mısır çeşidinin diğer çeşitlere göre hayvanlarda daha besleyici olacağ1 belirlenmiştir. Ham protein yönünden ele alındığında çeşitler arasında çok önemli bir farklılı̆̆ın olmadığı belirlenmiştir.

\section{KAYNAKLAR}

Açıkgöz E (2001). Yem Bitkileri (3. Baskı) Uludă̆ Üniv. Güçlendirme Vakfı Yayın No: 182, Bursa.

Akdeniz, H., Karslı, MA., Nursoy, H., Yılmaz, İ., 2003. Bazı Tane Sorgum Çeşitlerinin Besin Madde Kompozisyonu ve Sindirilebilir Kuru Madde Veriminin Belirlenmesi, Turk J Vet Anim Sci., 27(6): 1349-1355.

Akyıldız, AR., 1984. Yemler Bilgisi ve Laboratuvar Kilavuzu. Ankara Üniv. Zir. Fak. Yay. No: 895, Uygulama Kitabı No: 213, 236 s, Ankara.

Anonim., 2011. Quality assurance for animal feed analysis laboratories, http://www.fao.org/ag/agoinfo/home/documen

Anonim., 2015. Iğdırın Coğrafi Özellikleri Iğdır'ın İklimi ve Bitki Örtüsü, $\quad$ http://www.turksitesi.net/cografyasi-bitkiortusu/igdirin-cografi-ozellikleri.html (16.03.2016).

Ayranc1, R., Sade, B., 2004. Konya ekolojik şartlarında yetiştirilebilecek atdişi melez mısır (Zea mays L. indentata Sturt.) çeşitlerinin belirlenmesi. Bitkisel Araştırma Dergisi. 2: 6-14.

Başbağ, M., Demirel, R., Gül, İ., Saruhan, V., 1997. GAP Bölgesinde Silajlık Materyal Olarak Misır ve Sorgum Yetiştirme Olanakları. Türkiye Birinci Silaj Kongresi. Hasad Yayıncilık. 251-255. İstanbul.

Bressani, R., Conde, R., 1961. Changes in the chemical composition and in the distribution of nitrogen of maize at different stages of development. Cereal Chem., 38: 76-84.

Calsamiglia, S., Cardozo, PW., Ferret, A., Bach, A., 2008. Changes in remen microbial fermentation are due to a combined effect of type of diet and pH. J. Anim. Sci., 86(3):702-711

Denek, N., Deniz, S., 2003. Ruminant beslemede yaygın olarak kullanılan kimi kaba yemlerin sindirilebilirlik ve metabolik enerji düzeylerinin in vitro metotlarla belirlenmesi. II. Ulusal Hayvan Besleme Kongresi, 18-20 Eylül 2003, 13$17 \mathrm{~s}$, Konya.

Ebadi, MR., Pourreza, J., Jamalian, J., Edriss, MA., Samie, AH., Mirhadi, SA., 2005. Amino Acid Content and Availability in Low Medium and High Tannin Sorghum Grain For Poultry. International Journal Of Poultry Science, 4(1): 2731.

Erdogan, HE., 2013. Toprak Tanımlama Kilavuzu. T.C. Gida Tarım ve Hayvancılık Bakanlı̆̆ı, Tarım Reformu Genel Müdürlüğü, ISBN: 978-605-4672-20-2., 2013

Fonnesbeck, PV., Clark, DH., Garret, WN., Speth, CF., 1984. Predicting energy utilization from alfalfa hay from the Western Region. Proc. Am. Animal Science, (Western Section) 35: 305-308.

Juliann, RS., George, WS., Paulette, MK., Matías, LR., Frederick, EB., 2010. Relationship of source and sink in determining kernel composition of maize. Journal of Experimental Botany, 61(2): 511-519.

Kacar, B., 1972. Bitki ve Toprağın Kimyasal Analizleri: II. Bitki Analizleri. Ankara Üniversitesi Ziraat Fakültesi Yayını, Yayın No:453, 464 s, Ankara.

Kacar, B., 2012. Toprak Analizleri. Nobel yayınevi, 466 s, Ankara
Khalil, JK., Sawaya, WN., Hyder, SZ., 1986. Nutrient composition of Atriplex leaves grown in Saudi Arabia. J. Range Manage. 39: 104-107.

Kılıç, A., 1986. Silo Yemi (Öğretim, Öğrenim ve Uygulama Önerileri). Ege Üniversitesi, Ziraat Fakültesi, Bilgehan Basımevi. İzmir.

Kırtok, Y., 1998. Mısır Üretimi ve Kullanımı. Kocaoluk Basım ve Yayınevi, İstanbul.

Koca, YO., Erekul, O., Ünay, A., Turgut, Ü., 2009. Bazı melez mısır (Zea mays L.) çeşitlerinin Aydın ilinde birinci ve ikinci ürün performanslarının değerlendirilmesi. ADÜ Ziraat Fakültesi Dergisi. 6 (1): 41-52.

Koca, YO., Erekul, O., 2011. Bazı melez mısır çeşitlerinin performanslarının belirlenmesi. ADÜ Ziraat Fakültesi Dergisi, 8(2): 41-45.

Kutlu, HR., Görgülü, M., Çelik, LB., 2005. Genel Hayvan Besleme Ders Notu. Çukurova Üniversitesi Ziraat Fakültesi Zootekni Bölümü Yemler ve Hayvan Besleme Anabilim Dalı, Adana

Lopes, MA., Larkins, BA., 1991. Gamma-zein content is related to endosperm modification in quality protein maize. Crop Science, 31:1655-1662.

NRC., 2001. Nutrient Requirements of Small Ruminants: Sheep, Goats, Cervids, and New World Camelids. National Research Council of the National Academies, Washington DC.

Oddy, VH., Robards, GE., Low, SG., 1983. Prediction of in vivo dry matter digestibility from the fiber nitrogen content of a feed. In: Robards, G.E., Packham, R.G. (Eds.), Feed Information and Animal Production. Commonwealth Agricultural Bureaux, Farnham Royal, UK, pp. 395-398.

Öner, F., 2015. Determination of Chemical Quality Parameters with Yield and Yield components of Maize (Zea mays L.) Hybrids According to Various FAO Maturity Groups. Tekirdağ Ziraat Fakültesi Dergisi, 12(1): 1-7.

Parissi, ZM., Papachristou, TG., Nastis, AS., 2005. Effect of drying method on estimated nutritive value of browse species using an in vitro gas production technique. Animal Feed Science and Technology, 123-124(1): 119-128.

Sade, B., 2002. Misır Tarımı. Konya Ticaret Borsası Yayın No: 1. Konya.

Sade, B., Akbudak, NA., Acar, R., Arat, E., 2002. Konya Ekolojik Şartlarında Silajlık Olarak Uygun Misır Hibritlerinin Belirlenmesi. Hayvancılık Araştırma dergisi, 12(1):17-22.

Sağlamtimur, T., Tans1, V., Baytekin, H., 1998. Yem Bitkileri Yetiştirme. Çukurova Üniversitesi Ziraat Fakültesi Ders Kitabi No:74. Adana.

Sheaffer, CC., Peterson, MA., Mccalin, M., Volene, JJ., Cherney, JH., Johnson, KD., Woodward, WT., Viands, DR., 1995. Acide Detergent Fiber, Neutral Detergent Fiber Concentration and Relative Feed Value. North American Alfalfa İmprovemnt Conference, Minneapolis.

SPSS Inc., 1991. Statistical Package For The Social Sciences (SPSS/PC+). Chicago, IL

Tekce, E., Gül, M., 2014. Ruminant beslemede NDF ve ADF'nin önemi. Atatürk Üniversitesi, Vet. Bil. Derg, 9(1): 63-73.

Uribelarrea, M., Carcova, J., Otegui, ME., Westgate, M., 2002. Pollen production, pollination dynamics, and kernel set in maize. Crop Scienc, 42:1910-1918.

Van Soest, PJ., Robertson, JD., Lewis, BA., 1991. Methods for diatery fibre, neutral detergent fibre and non-starch polysaccharides in relation to animals nutrition. Journal of Dairy Science, 74: 3583-3597.

Vartanlı, S., Emekliler, HY., 2007. Ankara Koşullarında Hibrit Misır Ceșitlerinin Verim ve Kalite Özelliklerinin Belirlenmesi. Tarım Bilimleri Dergisi. 13 (3): 195-202.

Yazıcıŏ̆lu, N., Yeldan, M., 1987. Ruminant yemlerinin sindirilebilirliklerini saptamada uygulanan çeşitli invitro yöntemlerin karşılaştırılması üzerine araştırma. AÜ Fen Bilimleri Enstitüsü (Yüksek Lisans Tezi), Ankara. 
B. Keskin, H. Akdeniz, S. Temel, B. Eren

Yiğit, M., Ustaoğlu, S., 2003. Total ve Besin Maddesi Sindirilme Oranlarının Su Ürünleri Yetiștiriciliğindeki Önemi. E.U. Journal of Fisheries and Aquatic Sciences, 20(1-2): 287294.
Zilic, S., Milasinovic, M., Terzic, D., Barac, M., IgnjatovicMicic, D., 2011. Grain characteristics and composition of maize. specialty hybrids. Spanish Journal of Agricultural Research, 9(1): 230-241. 